\title{
Impact of Temperature on Crop and Higher Silk Production: Silkworm (Bombyx mori L.)
}

\author{
Imtiyaz Rasool Parrey* \\ Department of Chemistry, Govt. Degree College, India
}

Submission: March 07,2018; Published: April 13, 2018

*Corresponding author: Imtiyaz Rasool Parrey, Department of Chemistry, Govt. Degree College, Dooru Shahabad Anantnag Jammu and Kashmir, India, Email: imtiyazchmistry@gmail.com

\section{Abstract}

The regular contrasts in the natural parts impressively influence the genotypic articulation as phenotypic yield of silkworm product, for example, cover weight, shell weight, and case shell proportion. The varieties in the ecological condition every day and season to season stress the need of administration of temperature and relative moistness for feasible cover generation. The present survey paper examine in insights about the part of temperature and dampness on development and advancement of silkworm.

Keywords: Silkworm product; Shell proportion; Moistness

\section{Introduction}

Sericulture is the science that arrangements with the creation of silk by raising of silkworm. Silk is known as the ruler of materials because of its sparkling gloss, delicate quality, tastefulness, toughness, and pliable properties and is found in China in the vicinity of 2600 and 2700 BC. Silk beginning in the saliva of a bug is a characteristic stringy substance and is gotten from pupal homes or cases spun by hatchlings known as silkworm. The silk is favored over every single other kind of filaments because of its surprising properties like water permeableness, warm protection, coloring effectiveness, and gloss. Factors chiefly impact the physiology of creepy crawlies is temperature and moistness. In spite of wide variances in their environment, creepy crawlies demonstrate an exceptional scope of adjustments to fluctuating natural conditions and keep up their inside temperature and water content inside middle of as far as possible.

\section{Impact of Temperature}

The optimum temperature for normal growth of silkworms is between $20{ }^{\circ} \mathrm{C}$ and $28{ }^{\circ} \mathrm{C}$ and the desirable temperature for maximum productivity ranges from $23^{\circ} \mathrm{C}$ to $28^{\circ} \mathrm{C}$. Temperature above $30{ }^{\circ} \mathrm{C}$ directly affects the health of the worm. If the temperature is below $20{ }^{\circ} \mathrm{C}$ all the physiological activities are retarded, especially in early instars; as a result, worms become too weak and susceptible to various diseases. The temperature requirements during the early instars (I, II, III) are high and the worms feed actively, grow very vigorously, and lead to high growth rate. Such vigorous worms can withstand better even at adverse conditions in later instars. For the most part, the room temperature is low amid winter and blustery season, which ought to be directed by warming the stay with electric radiators or charcoal flames [1-4]. Thermoregulator-fitted electrical warmers are best since they don't produce any damaging gases. At the point when power turns out to be expensive and not accessible in numerous country zones of sericulture belt, legitimately dried charcoal can be utilized. In any case, the carbon dioxide and different gases discharged in this copying procedure are damaging to silkworms and they can be managed by giving more ventilation especially in daytime. Other than this, the entryways and windows ought to be kept shut especially amid night. Late in the day, as the outside temperature goes up, entryways and windows ought to be opened to enable warm air to the room. Amid summer season when day temperature is high, every one of the windows ought to be kept open. All the while, windows and entryways are secured with wet gunny fabric amid hot days to lessen the temperature and increment dampness $[5,6]$. Something else, reasonable air coolers can be utilized for this reason $[7,8]$.

There is plentiful writing expressing that great quality covers are delivered inside a temperature scope of $22-27{ }^{\circ} \mathrm{C}$ and that casing quality is poorer over these levels $[9,10]$. Be that as it may, polyvoltine breeds raised in tropical nations are known to endure marginally higher temperature and change with tropical climatic conditions [11]. So as to utilize bivoltine races in a tropical 
nation like India, it is important to have a steady case edit in a high temperature condition. High temperature antagonistically influences almost all organic procedures including the rates of biochemical and physiological responses [12], and can in the long run influence the quality or amount of cover edits in the silkworm and along these lines silk created. A few examinations [13-15] showed that silkworms were more delicate to high temperature amid the fourth and fifth stages.

\section{References}

1. Rao CG, Seshagiri SV, Ramesh C, Ibrahim Basha K, Nagaraju H, et al. (2006) Evaluation of genetic potential of the polyvoltine silkworm (Bombyx mori L.) germplasm and identification of parents for breeding programme. J Zhejiang Univ Sci B 7(3): 215-220.

2. Suresh Kumar N, Yamamoto T, Basavaraja HK, Datta RK (2001) Studies on the effect of high temperature on F1 hybrids between polyvoltine and bivoltine silkworm races of Bombyx mori L. International Journal of Industrial Entomology 2(2): 123-127.

3. Lakshmi H, Chandrashekaraiah M (2007) Identification of breeding research material for the development of Thermo-tolerant breeds of silkworm Bombyx mori. Journal of Experimental Zoology India 10(1): 55-63.

4. Begum NAR, Basavaraja HK, Joge PG, Palit AK (2008) Evaluation and identification of promising bivoltine Breeds in the silkworm, Bombyx mori L. International Journal of Industrial Entomology 16(1): 15-20.

5. Rahmathulla VK (1999) Management of climatic factors during silkworm rearing. The Textile Industry and Trade Journal pp. 25-26.

6. Sekarappa BM, Gururaj CS Management of silkworm rearing during summer. Indian Silk 27(12): 16.
7. Ueda S, Kimura R, Suzuki K (1975) Studies on the growth of the silkworm Bombyx mori. IV mutual relationship between the growth in the fifth instar larvae and productivity of silk substance and eggs. Bulletin of the Sericultural Experiment Station 26(3): 233-247.

8. Benchamin KV, Jolly MS (1986) Principles of silkworm rearing. In: Mahalingam S (Ed.), Proceedings of Seminar on Problems and Prospects of Sericulture. Vellore, India, pp. 63-106.

9. Krishanswami S, Narasimhanna MN, Suryanarayana SK, Kumararaj S (1973) Silkworm rearing Bulletin. 15/2 FAO Agricultural Services, United Nations Organizations, Rome, Italy.

10. Datta RK (1992) Guidelines for Bivoltine Rearing. Central Silk Board, Bangalore, India.

11. Hsieh FK, Yu S, Su SY, Peng SJ (1995) Studies on the thermo tolerance of the silkworm, Bombyx moriL Zsongriva.

12. Willmer CW, Stone G, Johnston I (2004) Environmental Physiology of Animals. Blackwell Science, Oxford, UK.

13. Ueda S, Lizuka H (1962) Studies on the effects of rearing temperature affecting the health of silkworm larvae and upon the quality of cocoons-1 Effect of temperature in each instar. Acta Sericologia in Japanese 41: 6-21.

14. Shirota T (1992) Selection of healthy silkworm strains through high temperature rearing of fifth instar larvae. Reports of the Silk Science Research Institute 40: 33-40.

15. Tazima Y, Ohuma A (1995) Preliminary experiments on the breeding procedure for synthesizing a high temperature resistant commercial strain of the silkworm, Bombyx mori L. Japan Silk Science Research Institute 43: 1-16.
Your next submission with Juniper Publishers will reach you the below assets

- Quality Editorial service

- Swift Peer Review

- Reprints availability

- E-prints Service

- Manuscript Podcast for convenient understanding

- Global attainment for your research

- Manuscript accessibility in different formats

( Pdf, E-pub, Full Text, Audio)

- Unceasing customer service

Track the below URL for one-step submission https://juniperpublishers.com/online-submission.php 